\title{
Historical Awareness as Social Capital for the Sustainability of Unitary State of the Republic of Indonesia
}

\author{
$1^{\text {st }}$ Suswandari \\ Lecturer in the Department of History Education \\ Faculty of Teacher Training and \\ Education \\ University of Muhammadiyah Prof. Dr. HAMKA \\ Jakarta, Indonesia \\ suswandari@uhamka.ac.id
}

\begin{abstract}
This study discusses the importance of historical awareness for the generations of a nation. The history of the national movement is a collective event of a nation, which can improve nation's awareness of an independent nationality. This study aims to analyze moral values in history as Social Capital which factored to the emergence of equality of fate and solidarity. This study uses a critical historical research method with a literature study as its primary reference. The result of this study confirms that historical awareness is Social Capital for the integrity and sustainability of the Republic of Indonesia. Globalization with all of its attributes allegedly can erode moral values and awareness of Indonesia's national history. The notion of historical awareness as Social Capital is another form of modality in development related to norms, social networks, trust to benefit, encourage participation, and social accessibility in national and state life.
\end{abstract}

\section{Keyword-Historical awareness, Social Capital}

\section{INTRODUCTION}

When talking about Indonesia, people point to a country that is vast, beautiful, rich (Nashir, 2019) in the Southeast Asian region, characterized by a diversity of populations that is unique and has a strong identity. The diversity of race, ethnicity, language, religion, and cultural behaviour are knitted together because the same direction and purpose of forming a nation (Anderson, 1983); (Kohn, 1965) which can determine his destiny. Bhineka Tunggal Ika is the beautiful terminology introduced by Sutosoma, the great poet in the Majapahit era. Bhineka Tunggal Ika resonates as a way to bring together many different people in the entire motherland (Ghufron, 2017). Unity and diversity in the context of multiculturalism theory is a sublimation of diversity which is bound to be one for the unity of Indonesia. The principle of multiculturalism that respects differences in diversity (Sahrasad, 2017) is an essential part of maintaining diversity as a force to maintain the existence and sustainability of the Republic of Indonesia.

The long journey of the history of Indonesia as a nation becomes an essential point for the basis of the awakening to achieve life in just, free from all forms of colonialism, and move together to build this beloved country (Suswandari, 2015). The History of Indonesia began with a period of animism and dynamism, and then followed by the influx of Hindu influence in 400 AD. Next came the development of Buddhism, and followed by Islam in the 8th century AD. In the 16th century, The Colonial period was started, which then caused a socio-political dynamic in the nation. These phases led to an agreement of the formation of a nation Indonesia which were proclaimed on August 17, 1945 (Suswandari, 2015). The Proclamation of Indonesian Independence on August 17, 1945, was a great achievement, and always commemorated with great joy every year. On August 17, 2020, Indonesia celebrates the 75th anniversary of independence; however, there is a lot to be done towards the ideals of independence itself. The dynamics of History of Indonesia, after 1945, has its uniqueness related to efforts to manage the country. Therefore, it still requires enthusiasm and hard work and commitment to building towards the nation's glory.

In the current global era, the context of history and history learning often become heated discussion, both among history teachers, parents, students, educators, and even policymakers. This condition is due to some educational policies. History as a subject in high school and vocational school always come and go, while the historical context in teaching social studies at the level of primary school is full of rhetoric and rote learning. The development of teaching is speedy and getting better with the support of computer technology, not only for teaching but also for communication between teachers and students (Hubackova, 2015).

Amid the current onslaught of global culture, history and historical learning are no longer regarded as important or exciting material in the education process. Since the demands of global life are dominated by demands of instant service, sophisticated technology as well as practical materialist life; as a result, many of our young generations 
in the 20th century lacked a complete understanding of the nation's history and nationality. The concept of change in history is often difficult to interpret (Halldén, 1997). This condition is very comprehensive and disconcerting for the establishment of Indonesia, a country that has been built with sacrifice and effort of its predecessors. "Never Forget History" as revealed by Bung Karno, the figure of Indonesia's proclamation. He implies how important it is to understand the history of the nation for the preservation of the state and nation pride.

Historical events contain "values and morals" that will foster a spirit of cooperation in the direction of ideals. The values, morals, and guidelines of a nation's life in the context of social science are called Social Capital.

This study aims to discuss the historical awareness as Social Capital in maintaining the integrity and sustainability of the unitary state of the Republic of Indonesia. This article explains the historical paradigm of historical understanding in understanding historical events, historical learning, Social Capital values, and historical morals to maintain the integrity and sustainability of the Republic of Indonesia during current global events.

\section{PARADIGM OF HISTORICAL AWARENESS IN UNDERSTANDING HISTORY EVENTS}

In today's highly sophisticated era, questions often arise from the younger generation who are referred to as the millennial generation, namely: "why should we study history". The availability of information technology reinforces surprising questions related to history learning in schools today, especially with the patterns of teaching history presented conventionally. Among these questions, include, "is it still necessary for us to study the history of the nation, starting from prehistoric times, historical times to the modern era today.

The millennial generation and onwards are the new generation In their assumption "everything is resolved quickly with one tap on the screen (smartphones, internet, social media, etc.), which can provide complete information. The landscape of their thinking patterns is different from the previous generation (Warto, 2017). In their view, history is the story of an event that is presented in a variety of easy access and attractive presentation in electronic media. What do we study history for? Learning history is to remember the past. A history that is only remembered will weaken and disappear one day (Zuhdi, 2017). Is it enough to study history to understand the facts of the past and understand how a nation was formed? (Susanto, 2015). Or is there another side? So that history subjects (especially in high school) become a separate subject, also in teacher training in colleges, there is a History Education Study Program and a History Department with scientific branches (Archeology, museology, etc.). The questions often cross the minds of the younger generation and become a burden for history teachers themselves. Good teaching of history encourages the emergence of curiosity about daily life, world history, medieval, and modern history (Berk \& Gültekin, 2011).
As an old-time memory, history teaches essential values, so the same mistakes do not happen twice. When examined in-depth, history provides many benefits in the formation of daily living behavior. Historia Magistra Vitae, history is the teacher of life. In the United States, teaching history in primary schools to universities is to socialize the principal values of the country, which mentioned in the Declaration of Independence such as liberalism, freedom of thought, democracy, and social, political, cultural, economic, and defense systems of the country. Furthermore, the contents of the teaching of history explain the figures of great Americans such as George Washington, Thomas Jefferson, Abraham Lincoln, Franklin Delano Roosevelt, and Dwight D. Eisenhower, which are related to their noble attitudes and other great works that became legacy when leading America (Yudohusodo, 2015). Even the historical museum is vital to visit by families in America. It is directly proportional to the museum's readiness to provide clear and accurate information about history by utilizing advanced technology, likewise, in Germany, France, and England. The values and morals of each historical event related to efforts to strengthen nationalism are presented in enjoyable learning activities and processes. The explanation of the European Nation's colonization system in the Archipelago teaches to an anti-colonial spirit, and also aroused a sense of independent nationhood. The spice trade in Indonesian history not only brings a bleak story but also becomes a unifying force (Farid, 2017).

Understanding of national history has a critical role for a nation to formulate its existence from the beginning until now. Understanding history, as a nation's collective memory and cultural symbol, has united the Indonesian nation to face difficulties in formulating a national (Warto, 2017) identity that is united in its diversity. To be able to manifest real behavior in the life of the nation, and society, it is necessary to grow what is called historical awareness. Therefore, the importance of historical awareness related to events that have occurred becomes the focus of the study.

Historical awareness is defined as an intellectual orientation, an attitude of the soul that needs to understand the understanding of national personality precisely (Soedjatmoko, 1984). This historical awareness leads humans to the understanding of knowing oneself as a nation, the self-understanding of the nation, to the doubt of a nation, to the issue of "what we are, what we are, what we are ... ". Historical awareness in humans is crucial for the development of the national culture (Soedjatmoko, 1984). Historical awareness in this context is not just broadening knowledge. Still, it must also be directed towards the awareness of cultural values that are relevant to develop culture itself.

Historical awareness in the context of fostering national culture and awakening consciousness in the nation is a social unity that is realized through a historical process, which finally unites many small nations into a large nation (Kartodirdjo, 1989). Thus the indicators of historical awareness can be formulated as living the meaning and nature of history for the present and the future; know themselves and their people; civilizing history for fostering national culture; and maintain the heritage of the nation's 
history (Kartodirdjo, 1989). Indonesia is very vulnerable to social conflicts. It is due to its vast geographical situation, connected by sea and land, diverse ethnic building structures, abundant natural resources, and scattered in various regions, and the equality of social welfare has not reached in today's modern era. In the context of global capitalism that hit Indonesia today, it turns out that it caused a high social gap between the haves and the havenots in the cities or villages. The result is a feeling of dissatisfaction that will psychologically instill into a potential conflict with high escalation. Therefore, various horizontal conflict events that have occurred and may be partly caused by the factors above can be avoided through the awareness of history that tomorrow is better. It becomes a great lesson to look for a solution, growing understanding, and muted emotions and mutually strengthen themselves in better activities for the benefit of the nation and state.

In regards to the psychological aspects of individuals, historical awareness must be grown as part of maintaining the identity and integrity and sustainability of a nationstate (Anderson, 1983), including the united state of the Republic of Indonesia. Global developments have their gaps, which can erode and undermine the nation's attitude and sense of the nation, because of its appeal and ease. In other words, the sense of nationalism for the millennial generation began to thin out due to the opportunities and easiness offered by the global world.

\section{HISTORICAL AWARENESS AS A SOCIAL CAPITAL}

The term Social Capital began to be discussed since 1916 by the writings of L.J Hanifan, an educational figure, titled The Rural School of Community Center (1916) to improve the living conditions of the community through community involvement and other social attributes (Hanifan, 1916). In this case, society is seen as a cultural entity that has social values as a binding and real identity of human life. The term Social Capital has not appeared in the scientific literature for decades because a lack of parties agrees with the concept. In 1956, a group of Canadian urban sociologists used it and was strengthened by the emergence of the Social Exchange theory from George C.

Homans in 1961. It is stated that behaviors can influence each other in social relationships that can create balance and harmony (Mighfar, 2015). The concept of Social Capital emerged in the discussion of the ties of the social community.

Social Capital is generally understood as a resource owned by the community in the form of norms or values that facilitate and build cooperation (Fathy, 2019) through a network of interactions and communication in a harmonious and conducive manner as an essential part of determining organizational success. Social Capital is believed to be able to provide strength or power in some conditions of an organization and organizational culture (Jones, Gareth; 2010). In the context of the nation's history, Indonesia can be interpreted as a large organization with all its cultural identities; it certainly has some form of social capital, to strengthen the concept of the unity of the nation.

History, as a past event, explains the social, political, economic, and cultural background of a nation with value and moral content in each particular event. Values and morals in historical events are the Social Capital pillars of solidarity, harmony, and balance in social relationships that are motivated by the same sense of unity. The struggle to face European colonialism in the archipelago, which began with the spice trade, was understood not to be only trade in the local community on the international market. The events of international trade at that time illustrated the trade process that enabled the exchange of values and culture that helped shape the identity of Indonesian people (Farid, 2017).

The dynamics and ideals of a nation cannot be comprehended without a profound reflection on the history and experience of the nation itself. Therefore, historical awareness as an intellectual orientation (Aman, n.d.) is the soul and attitude of an individual in his national community to become Social Capital related to understanding his national personality. Historical awareness as Social Capital is an attitude as well as a bond to the birth of independent national solidarity and able to determine their destiny, their own identity, and have authority among other nations in the world. Historical awareness as Social Capital is a significant part of strengthening the value of a character to strengthen solidarity and togetherness over the past. Thus, the millennial generation can see the various social problems faced today are a reflection of the past and have wisdom in predicting the future so that mistakes do not occur twice.

National history in each country has a function as a milestone for a nation that is in the process of becoming a large, united, and solid nation. To be able to understand Indonesia well, historical awareness is needed as a foundation for the same feelings and the same history as a nation. Through historical awareness, it will be able to provide value-wisdom for those who learn it. History teaches how to make choices to consider from various opinions carefully, history unites concerning care and awareness, and history teaches character because the study of historical events fosters humility before the ability to see the vast history of humanity (Aman, 2009).

\section{CONCLUSION}

Thus, it can be concluded that historical awareness is viewed as Social Capital because there are social values in historical events, such as togetherness, goodwill, friendly feelings and mutual sympathy that will form to national solidarity. Mutual trust, the existence of norms, and social networking can be used to solve various social problems encountered. The text of Indonesia's national history explains various forms of historical events which contain various elements as a dimension of Social Capital. In connection, the neglect of the nation's history in development can be interpreted as irresponsibility towards the integrity and sustainability of the unitary state. The current process of teaching history faces serious challenges 
related to the issue of globalism which can undermine the attitude of nationalism wherever nationality is located. The exploration of Social Capital from various national historical events is an alternative effort so that historical awareness in the unitary state of the Republic of Indonesia is guaranteed to be sustainable and maintained. The new paradigm in learning history indeed becomes an important thing that should not be ignored to strengthen historical awareness through formal education. Gradually, strengthening historical awareness can be broadened by involving the community directly through formal and informal channels. Development that does not involve historical values becomes a sign of weakening in the context and spirit of nationalism.

\section{REFERENCES}

[1] Aman. (n.d.)Sejarah dan Problematika Pendidikan. Aman. (n.d.)Sejarah dan Problematika Http://Staffnew.Uny.Ac.Id/Upload/132303695/Penelitian/B
Hendidil 15.JURNAL.Pdf.

[2] Aman. (2009). Kesadaran Sejarah Dan nasionalisme Pengalaman Indonesia. Informasi Nomor XXXVI.

[3] Anderson, B. (1983). Imagined Communities: Reflection on the Original Spread of Nationalsim The Thetford Press.

[4] Berk, N. A., \& Gültekin, F. (2011). The topics that students are curious about in the history lesson. Procedia - Social and Behavioral Sciences, 15, 2785-2791. https://doi.org/10.1016/j.sbspro.2011.04.189

[5] Farid, H. (2017). Sejarah Tak Cukup Sekedar Diingat. Kompas.

[6] Fathy, R. (2019). Modal Sosial: Konsep, Inklusivitas dan Pemberdayaan Masyarakat. Jurnal

[7] Pemikiran Sosiologi, $6(1)$, https://doi.org/10.22146/jps.v6i1.47463 [7] Ghufron, F. (2017). Merawat Marwah Kebhinekaan. Kompas. Giddens, A. (2002). "The Third Way: The Renewal of Social Democracy. Jakarta: PT SUN.

[8] Halldén, O. (1997). Conceptual change and the learning of history. International Journal of Educational Research, 27(3), 201-210. https://doi.org/10.1016/S0883-0355(97)89728-5

[9] Hanifan, L. J. (1916). The Rural School Community Centre. Https://Journals.Sagepub.Com/Doi/10.1177/0002716216067001
18 ,
$130-138$
Retrieved from https://journals.sagepub.com/doi/10.1177/000271621606700118

[10] Hubackova, S. (2015). History and Perspectives of Elearning. Procedia - Social and Behavioral Sciences, 191, 1187-1190. https://doi.org/10.1016/j.sbspro.2015.04.594

[11] Kartodirdjo, S. (1989). Fungsi Sejarah dalam Pembangunan Nasional. Historika No.1 Tahun I. Kohn, H. (1965). Kohn, Hans H.J Van Nostrand.

[12] Mighfar, S. (2015). Telaah Konsep George C. Homans Tentang Teori Pertukaran Sosial. Jurnal Lisan Al-Hal, 9(2), 261-287. Retrieved https://journal.ibrahimy.ac.id/index.php/lisanalhal/article/view/98

[13] Nashir, H. (2019). Indonesia dan Keindonesiaan Perspektif Sosiologis. (K. Yayum, Ed.) (III Desemb). yogyakarta: Penerbit Suara Muhammadiyah. Retrieved from .www.suaramuhammadiyah.id

[14] Nasution, R. D. (2018). Pengaruh Modernisasi dan Globalisasi terhadap Perubahan Sosial Budaya di Indonesia. Jurnal Kominfo, $1-14$.

[15] Sahrasad, H. (2017, April). Indonesia dan akomodasi Multikultural. Kompas.

[16] Soedjatmoko. (1984). Dimensi Manusia dalam Pembangunan: Pilihan Karangan. Jakarta: Lembaga Penelitian, Pendidikan, dan Penerangan Ekonomi dan Sosial.

[17] Susanto, H. (2015). Strategi Mengembangkan Historical Emphaty Dalam Pedagogi Sejarah. In Prosiding Internatiomal Conference Contribution of History For Social Sciences and Humanities. Malang, Indonesia.

[18] Suswandari. (2015). Makna Sejarah Dalam penguatan karakter dan Identitas Bangsa. In Dewa Agung G.A (Ed.), Prosiding
Internatiomal Conference Contribution of History For Social Sciences and Humanities. Malang, Indonesia: Fakultas Ilmu Sosial Universitas Negeri Malang.

[19] Warto. (2017). Internalisasi Nilai- Nilai Sejarah Sebagai Upaya Meningkatkan Rasa Nasionalisme dan Sadar Sejarah bagi generasi muda.

[20] Widiastuti, E. H. (2013). Spirit dan Aktualisasi Nilai Kesejarahan Untuk Pemahaman Rasa Kebangsaan (Edisi Khusus Dies Natalis Vol XX 23 Agustus). [23] Yudohusodo, S. (2015). Pengajaran Sejarah. Kompas.

[21] Zuhdi, S. (2017). Menggali Ulang Sejarah Rempah Nusantara. Jakarta: Kompas. 